Multidisciplinary

SCIENTIFIC JOURNAL OF MARITIME RESEARCH

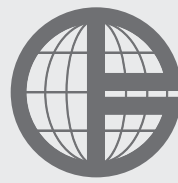

University of Rijeka

Faculty of Maritime

Studies Rijeka
Multidisciplinarni

znanstveni časopis

POMORSTVO

\title{
Container ports competition in light of contemporary liner shipping market dynamics
}

\author{
Mohamed El Kalla1, Damir Zec ${ }^{2}$, Alen Jugović ${ }^{2}$ \\ ${ }^{1}$ Arab Academy for Science, Technology \& Maritime Transport, 1029 Alexandria, Egypt, e-mail: mohmedelkalla@aast.edu \\ ${ }^{2}$ University of Rijeka, Faculty of Maritime Studies Rijeka, Studentska ulica 2, 51000 Rijeka, Croatia, e-mail: zec@pfri.hr
}

\begin{abstract}
Since the development of containers and Intermodalism in the late 1960's, containerization is constantly growing and penetrating almost all seaborne trade sectors, as by 2016 nearly1.7 billion tons were transported by container [8]. Moreover, Container ports play an important role as nodes in the supply chain and focal points for containerized cargo as they complement and add value to the shipping lines and shippers' objectives. Moreover, competition among container ports is taking place at all levels regionally, nationally and internally. In the same context, shipping lines are competing vigorously and increasing their fleets in both size and number of vessels, resulting in excess market supply. Recently, shipping lines are consolidating rapidly by means of vertical and horizontal integration through mergers, acquisitions and forming alliances to cool down competition and backup each other as well as escape bankruptcy. This policy increased the market concentration and shipping lines bargaining power and exposed container ports to more competitive environment as well. The key point put forward in this paper is that the competitive battle among container ports will increasingly be fought with the presence of recent shipping lines market concentration. This paper illustrates the contemporary dynamics in the container shipping market. In that respect, the paper is divided into three main sections. The first one presents the port competition conceptual definition, types and landscapes. The second one outlines the analyses of the existing carriers' contemporary market dynamics. Finally, discusses the possible outcomes of different development policies of shipping companies, and how they affect ports' effectiveness and competitiveness.
\end{abstract}

\section{ARTICLE INFO}

Review article

Received 16 November 2017

Accepted 15 December 2017

Key words:

Port competition

Shipping lines market

Shipping line alliances

\section{Introduction}

In recent decades, globalization, market integration, and global reorganization of investment and labour forces reshaped the world production and consumption map. Moreover, containerization and inter-modality fueled the development of the international transport network, as in 2016, the seaborne containerized cargo reached around 1.7 billion tons transported by container ships and container ports handled around 0.7 billion TEUs [8]. This increased the role of ports in the global supply chain and extensively impacted port competition.

Port rivalry has become so vigorous and multi-faceted concept due to continuous changes in the ports and shipping market condition, causing an increase in competition among operators in the same port, among adjacent ports, multi-port gateway regions as well as among whole port ranges [21]. Privatization of ports and injections of private investments also powered competition between ports, as from 2000 to 2016, the private sector invested in 292 projects with approximately 68.6 billion USD in 63 countries with emerging and developing economies [29].

Moreover, the growing trend of mergers, acquisition, alliances of shipping companies as well as deployment of huge carriers magnifies shipping market concentration, resulting in an increased bargaining power against ports. In addition, it reduces the number of weekly liner services: for example the North Europe-Far East weekly services declined from 35 in 2006 to 26 in 2012, then to 21 in 2015 and only 17 in 2017. This concept of larger ships with fewer services fueled the competition among container ports, knowing that one weekly service of such giant vessels contributes to around 450,000 TEUs in ports throughput annually [22]. 
This paper aims to investigate the current trends in port competition by analysing the dynamics of the carriers' market. This will be carried out by presenting the concepts, definitions and thorough analyses of the market conditions. In that respect, the paper is divided into three main sections. The first one presents the port competition conceptual definition, types and landscapes and their consequences in everyday life. The second one outlines the analyses of the existing carriers' market dynamics. Finally, the third one discusses the possible outcomes of different development policies, especially those adopted and implemented by shipping companies, and how they affect ports' effectiveness and competitiveness.

\section{Ports competition}

Ports with their importance and nature as major nodes in the supply chain are experiencing a dynamic competitive environment. Understanding the conceptual meaning of competition, types of competition as well as ports competition landscape are very important if one wants to evaluate the influence of the carrier's market behaviour on ports competitiveness.

\subsection{Conceptual definition}

Port competition concept was not a well-defined concept for its complex nature. Henceforth, the characteristics and nature of competition depend mostly on the type of the port involved; for example, the environment is very different if the port is a gateway port, local port or transhipment port, as well as on the type of cargo handled (for example, consumer products, wet bulk or dry bulk). Consequently, most researchers attempt to define competition as either a process or a state of affairs. When competition is demonstrated as a process, some researches express entrepreneurs as the key to success [12].

Knight (1921) was one of the first who focused on the notion of risk. He asserted that risk taking is the function of the entrepreneur success for their efforts. The common theme of this debate was that a competitive market system is one where entrepreneurs compete without obstruction with each other for success. The struggle characterizes market contestability in which the strong competition is the theme of the market. Another definition of port competitiveness is the ability of the port to create added value, create core business and develop productive activity within its market. As such, the most competitive port will be able to establish a differentiated policy and gaining more customers than its competitors [4].

\subsection{Port competition types}

The factors influencing port competition may vary according to its level. The competitive strength of single undertakings inside a port is determined mostly by the aspects of production (labour, capital, technology, and en- ergy). Rivalry among ports, port clusters and port ranges is mainly affected by regional factors, for instance the location, the existing infrastructure, the industrial development, government policy and the port performance (measured as proxy variables, such as the number and frequency of liner services, and transhipment cost, storage and hinterland transportation) which bear considerable importance for this research [17].

Port competition can be categorized into three main categories that show the complete concept of seaport competition and explain the relationship between ports and port activities [30]. Figure 1 presents the types of port competition categories that most ports are likely to face, all or some of them, in their business: inter-port competition, intra-port competition, and inter-port competition at the port authority level.

Inter-port competition can be defined as the competition between different ports. The main factor showing if ports are experiencing inter-port completion is the share of common hinterland or foreland [5]. Inter-port competition can be classified into three subcategories. The first is competition between the whole port range and coastlines; an example is the competition among container ports on the East and West Coast of North America

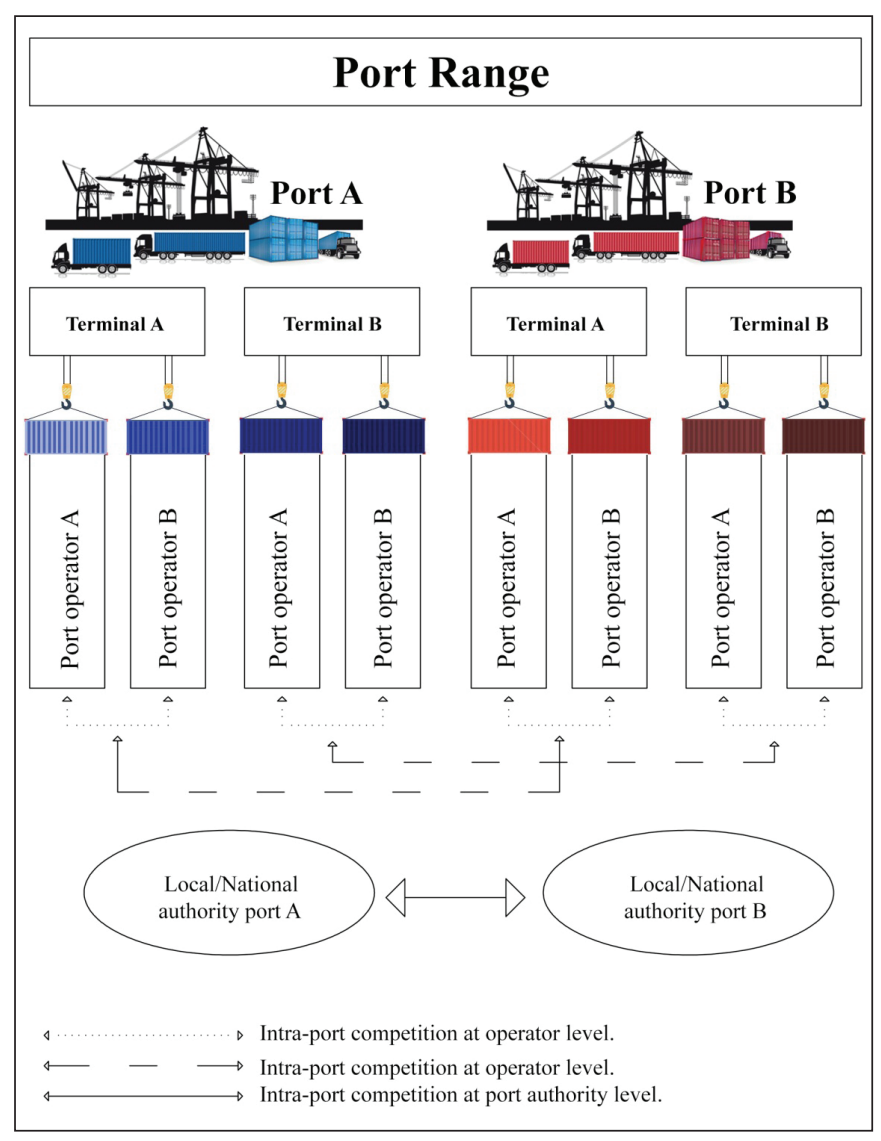

Figure 1 Types of Port Competition

Source: Author, adapted from [17] 
as well as in Europe (among ports in the Hamburg-Le Havre range). The competition increases mostly due to the expansion of both the multimodal and long-distance transport systems. The second type is the competition between ports in different countries; the example is competition between Vancouver in Canada against Tacoma and Seattle in the United States. In Europe, this can be recognized between Rotterdam in the Netherlands and Antwerp in Belgium. The third type is competition at the national level where competition takes place among different ports within the same country as ports are serving the same overlapped hinterlands; the notable examples are the competition between Los Angeles and Long Beach in California or between Qingdao and Dalian in Northern China [30].

Inter-port competition may exert high risk of losing traffic [5]. Therefore, ports should keep their competitive edge especially in respect of ever larger container vessels as well as in respect of a high consolidation of shipping lines and their bargaining power. Ports should have the same development pace as shipping lines and invest in infra/superstructure to accommodate their mammoth container vessels. Moreover, they are expected to continuously improve efficiency of cargo handling and to shorter ships' turnaround time in port, to avoid losing customers, having in mind shipping liner companies that are more flexible than ports.

A vertical integration of shipping liner companies also influences intra-port competition. For instance, the agreement between CMA CGM and PSA in Singapore aiming to establish a new joint venture company to operate 4 berths in the port of Singapore (to handle nearly 3 million TEUs annually) will definitely affect Port Klang because approximately $20 \%$ of the Port Klang's throughput is carried by CMA CGM [10].

The second type of port competition is intra-port competition which is mainly linked to terminal operators, ownerships and port administration. This type of competition can assume two forms. The first is a direct competition between terminals operating in the same port; a notable example is in the port of Antwerp where three container terminals operators Hessenatie, Noord Natie and Katoenatie compete for the same market share. Similarly, in the port of Rotterdam, the rivalry between APM and ECT can be clearly recognized. The second form of the intra-port competition can be identified when operators using the same terminal compete among each other. The level of competition directly determines the flexibility of terminal operators - the lower the level of intra port competition, the higher the flexibility of the port, in particular in respect of the pricing policy [28]. A special case occurs when the port authority acts as a competitor, i.e. when a port authority has shares in port undertakings or terminal operators.

In this context, national port policies should always aim to enhance the performance and the efficiency of the whole port activities within the country. Since intra-port competition occurs within a port, it is, therefore, not directly affected by specific aspects of national policies and regulations. Taking these into account, port authorities are expected to ensure contestable conditions for all players within the internal port market. Meanwhile, [30] argued that a port authority should play an active role in encouraging cooperative activities that optimize port economies of scale and scope.

The third type of port competition is inter-port competition at port authority level i.e. taking into account the utility mission of seaports. This type of competition exists between port authorities at a national, local, regional or international level. It can be clearly identified when the rival ports share the same market and handle the same cargo type(s). A clear example of that kind of competition is the competition between ports within the Hamburg-Le Havre range, container ports in the Mediterranean, Hong Kong and Singapore in the Far East and between New York and Halifax on the East Coast of North America [32]. These ports, to a large extent, compete for containers and are investing to keep pace with the future demand and to increase their throughput and market share.

\subsection{The Landscape of Port Competition}

In the early days of containerization, the inter-port competition was not so significant, as most of the ports were known for being either monopolistic or oligopolistic for its traffic which was limited and concentrated upon the port's geographical area. Nevertheless, the development of containerization and multimodal transportation has considerably reformed the business environment and forced ports to improve their attractiveness in terms of hinterland accessibility, productivity, and quality of services, reputation and reliability. Recently, competition and competitiveness are crucial for any port or terminal operator as this will radiate in all operation, planning and development strategies.

Moreover, the landscape where ports competition takes place is very important for decision makers. The main forces that shape the completion in any port (Figure 2) are:

1) the rivalry among existing competitors

2) the threat of new competitors

3) the potential for global substitutes

4) the bargaining power of port users

5) the bargaining power of port service.

These forces will affect nearly all ports in all sizes and will influence the port investment plans, efficiency, pricing policies. Finally, ports' profitability will mainly depend on how managements deal with these forces and how decision-makers tackle these challenges. Shipping market dynamics and how it affects the carriers bargaining power and exert pressure on ports competition is very important to be investigated before port managers take any strategic decision. 


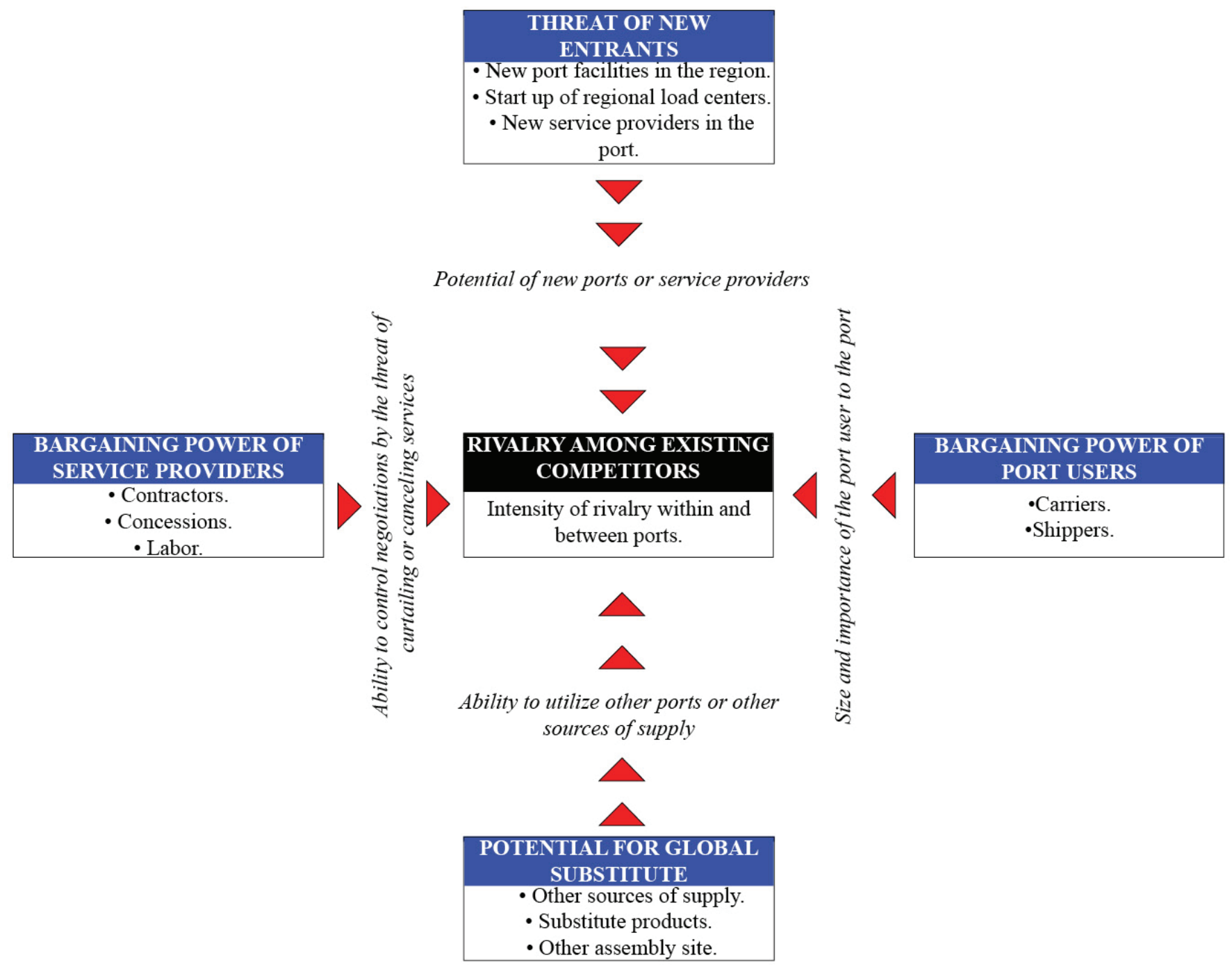

Figure 2 Ports Competition Landscape

Source: Author, adopted from [31]

\section{Liner shipping marketing dynamics}

The ongoing dynamics in the highly competitive container markets made competition among container ports highly connected to shipping lines dynamics and transformations. Alliances and shipping lines merging are having a great influence on inter-port competition as they may significantly affect the balance of bargaining power between ports and carriers [22]. Container shipping lines in the first ten years of containerization were not facing any problem with profitability as they were secured by the revenue pooling agreements based on conference tariffs [23]. But over the last decade, container carriers have significantly financially drifted in comparison to other industries and that forced them to focus on optimization of all processes through horizontal and vertical integration.

Horizontal integration has been performed mainly through three distinctive forms:
1) trade agreements (like liner conferences),

2) operating agreements (that is, vessel sharing agreements, slot chartering agreements, consortia and strategic alliances) and

3) mergers and acquisitions.

The process resulted in a significant consolidation, causing $70 \%$ of the market to be controlled by the seven largest operators in 2016 [14].

At the same time the vertical integration has been achieved by many shipping lines since the late 60s (for example, Mitsui OSK Line (MOL), Evergreen, K-Line and Maersk), resulting in their significant involvement in terminal operations and logistic activities [24]. This has been done to benefit from economy of scale, customer retention as well as stabilization of revenue [26]. Vertical integration caused the increased competition not only among ports but also between the whole supply chains. 
Recently, the competition among liner shipping companies and the desire to increase the market supply resulted in gigantic vessels, which lead to a negative balance sheet to many of them. Consequently, they rushed toward mergers, acquisitions and alliances to save their existence as well as to strengthen their businesses in port operations as a toll of reducing cost and gain control.

\subsection{Liner shipping companies financial condition}

The containerization industry was increasing dramatically (by about 8\% from 1990 to 2010). Liner shipping companies were competing mainly by ordering gigantic container ships, thus causing the world fleet to grow by almost 15\%. It is in line with the expectations that the global container trade will grow in double digits. Unfortunately, the world economy grew more slowly. Consequently, the global container demand grew less than 1 per cent in 2015 and a huge over capacity of container shipping tonnage was deployed in the market. In the same context, since 2007, the industry has been witnessing a very poor financial outcome as a result of the severe competition between carriers causing the Hanjin Shipping Co. to bankrupt at end of 2016 and leaving 2.9\% of the market share to competitors. Moreover, Drewry believes that, in 2017, the carriers' financial results and profitability will continue to fall, thus forcing financially weak carriers to address their cost structures. At the same time, the operational stress experienced at the challenging market conditions, inflating debts and negative cash flows for an extended period of time will exert serious tensions on the carriers' business capabilities, causing further industry consolidation [25].

Figure 3 shows the shipping industry average Altman Z- score from 2010 to 2016 . Altman Z-score is the creditstrength test that gauges likelihood of bankruptcy, based on a number of metrics from a company's public state- ments. The safe score is above 3 while score below 1.8 means the company is probably heading for bankruptcy. It is clear that the industry score since 2011 is showing a high tendency for companies' bankruptcy, which reached 0.9 in 2016 (before Hanjin figures were excluded), and the score increased only to 1 after Hanjin was eliminated. This means that the industry could lose more companies if its financial situation is not improved. Shipping lines are always seeking a way to slim down operating costs and capital expansion as, between 2011 and 2016, the industry reduced its capital expansion (CAPEX) by half; from 25.2 billion to only 12.4 billion [2]. Finally, in 2017, the only way for the industry to survive is to shelter among each other by mergers and acquisitions, as it could be the only "lifeboat" for many of them, as well as to be involved in alliances to optimize their economy of scale.

\subsection{Shipping Lines Alliances and Market Concentration}

The horizontal integration policy of the shipping liner companies, and backing up themselves through alliances, is not a new act. However, the recent pace of consolidation could be driven not only to overcome their financial deficiencies but for geopolitical reasons as well. Figure 4 shows the consolidation and partnerships that took place since the late 90s up to now. During that period, many companies disappeared, being swallowed up or merged with other companies. Up to the year 2001, the top 30 container liner companies in addition to the alliances covered less than $50 \%$ of the market share, by 2011 this percentage increased to $70 \%$. In 2014, the market share of the alliances only reached $50 \%$ [27]. In the same context, in 2017, only 3 alliances controlled nearly three quarters of the whole market. The significance of the resent alliances is the change of the market leaders' policies, like those of Maersk and MSC, from operating solely to the engagement into alliance and forming the $2 \mathrm{M}$ alliance that controls

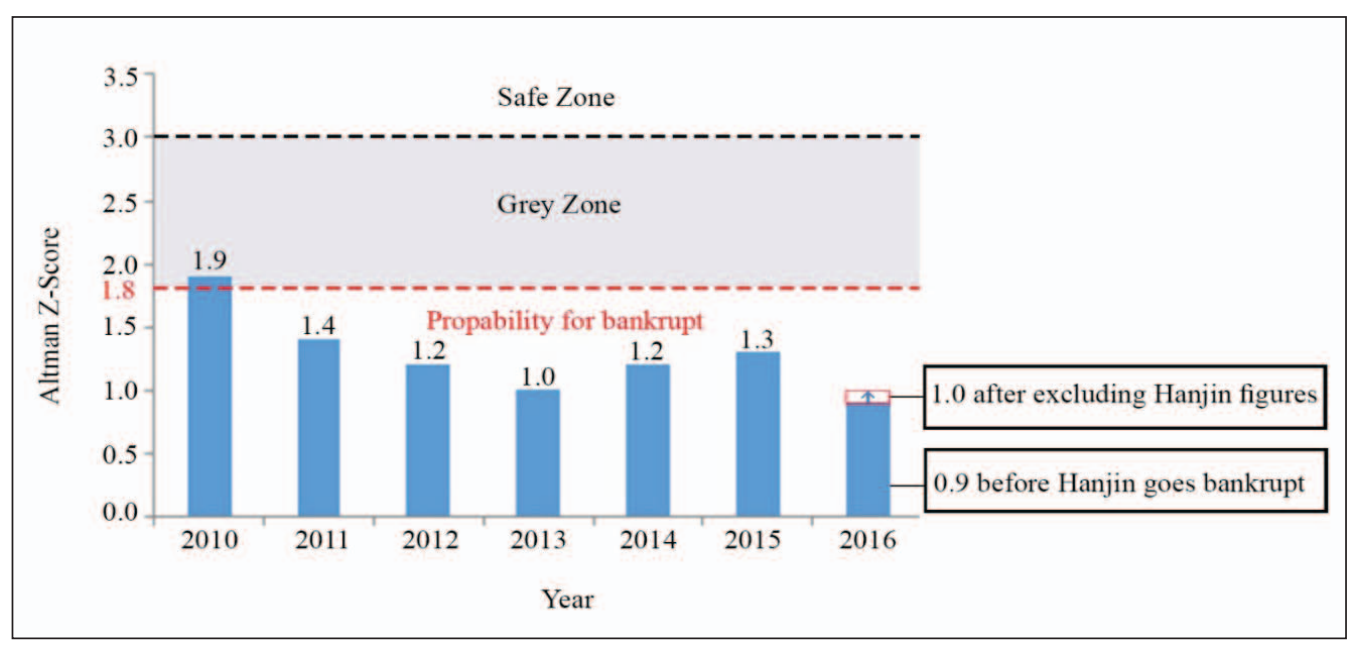

Figure 3 Shipping Industry Average Altman Z- Score from 2010 to 2016 


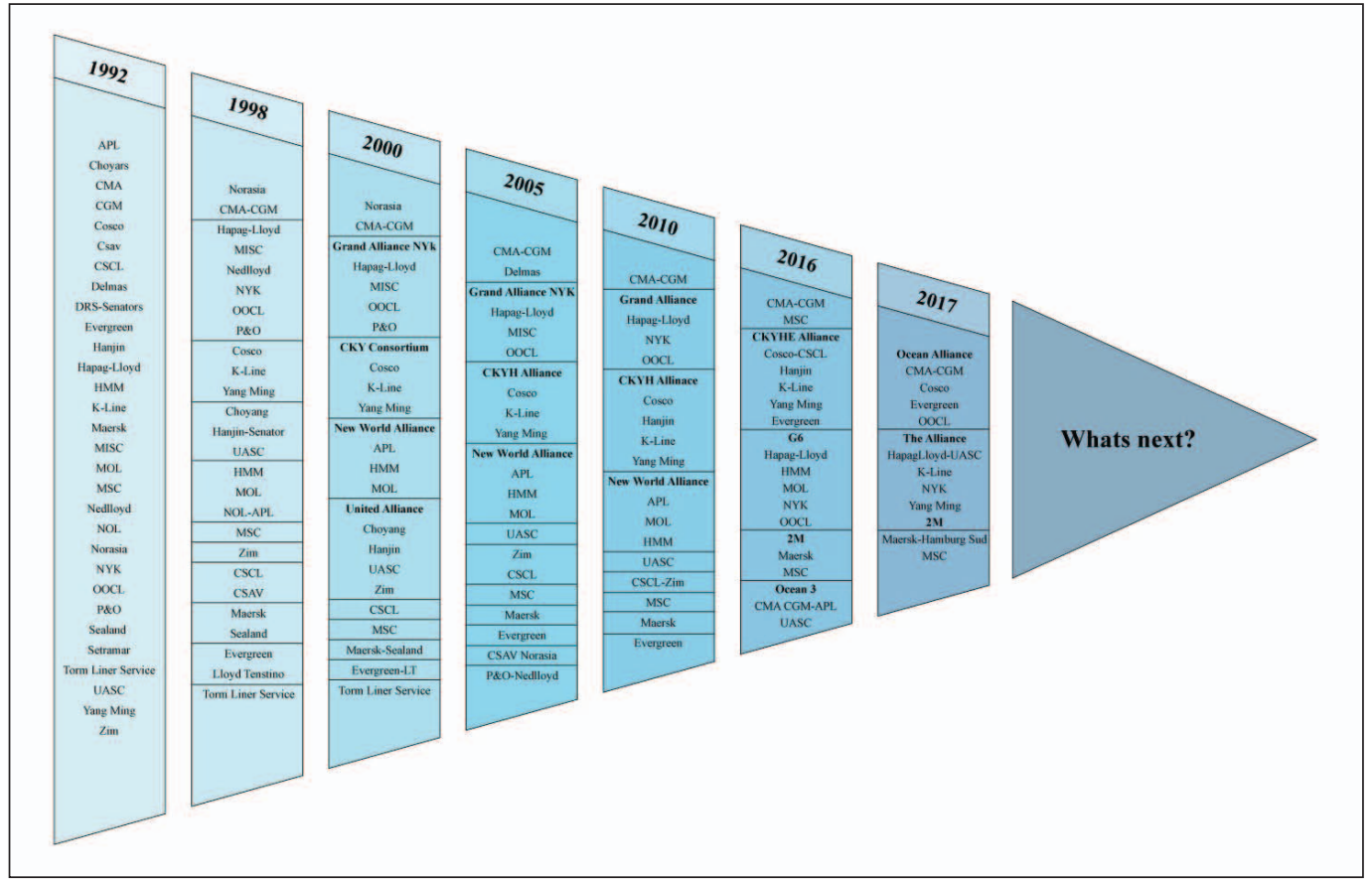

Figure 4 Evolution of Shipping Line Alliances

Source: Author, data from [9]

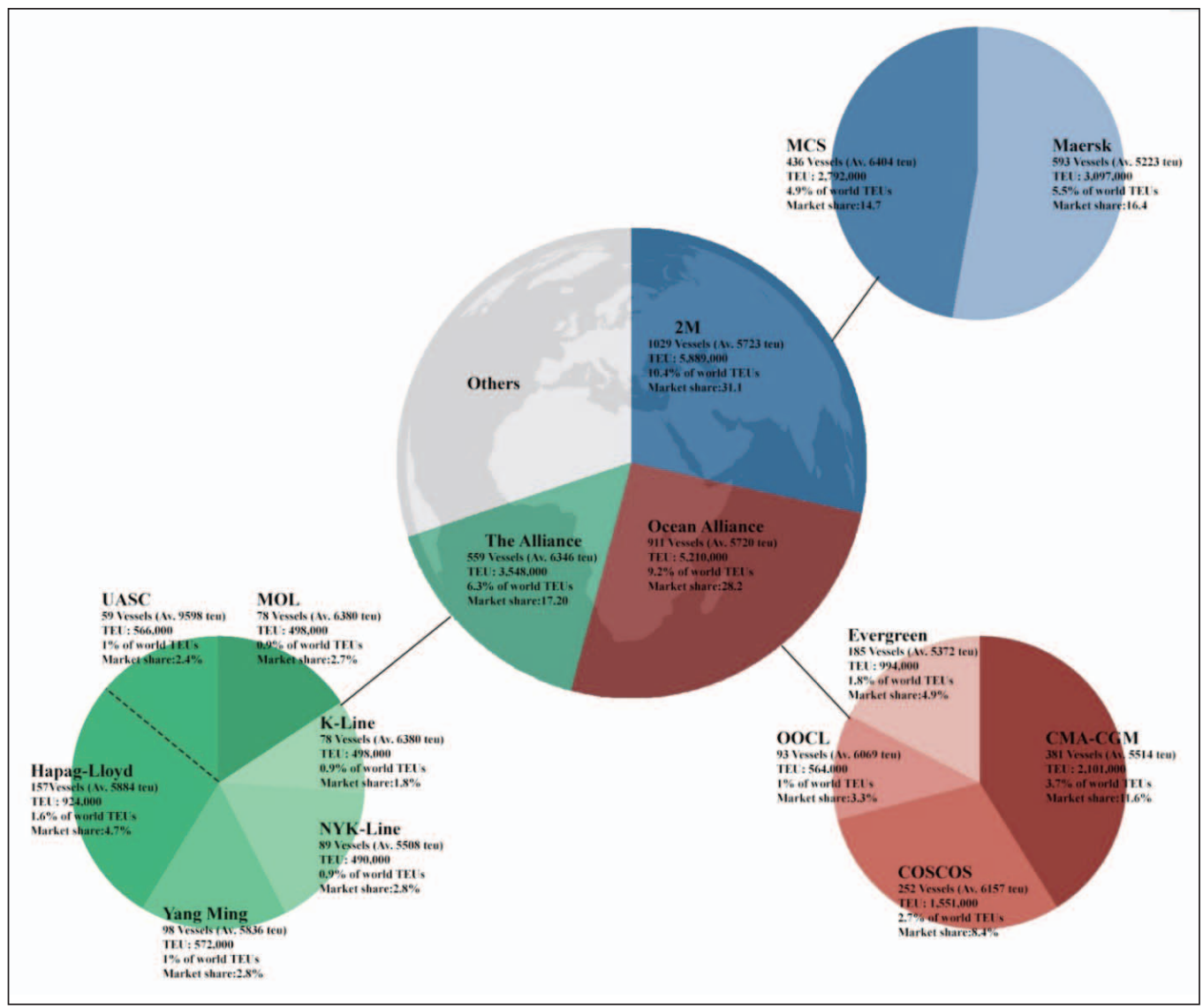

Figure 5 Alliances Carrying Capacities and Market Share in 2017 
nearly one third of the market share. This act alone significantly increases the market concentration and strengthens the shipping lines bargaining power toward ports.

Geopolitical reasons are also strongly present in this wave of alliances as economic super powers usually need and want to secure their supply chains. The new shipping alliances are showing a geopolitical flavour as each alliance is dominated by a flag of country or continent in the sense that the $2 \mathrm{M}$ is European and the Ocean alliance is mainly Chinese, in spite of the presence of the French CMA CGM as a leading share in the Ocean alliance with its $11.6 \%$ market share. China is in control of about $16.6 \%$ of the market share either directly through its own state company "COSCO Shipping Line" or indirectly through the presence of the Hong Kong's Company (OOCL) and Taiwanese company (Evergreen). Moreover, the COSCO already proposed $\$ 6.3$ billion to buy OOCL by which it will be the third largest carrier (Buxbaum P., 2017). In the same context, the Chinese state-owned company "China Merchants Holding" owns $49 \%$ of the terminal operating company "Terminal Link" and the remaining 51\% is owned by CMA CGM [16]. This means that in case of any future acquisition made by another Chinese state-owned company, the distribution of power within the alliances and even in the whole industry will be changed. This raises the question of how concentration in the shipping industry will affect the port operation business and competition.

Figure 5 shows the carrying capacities of the main three alliances member and their market share. It is clear that the all carriers are operating 2,499 vessels (over a capacity of 1000 TEUs) representing $60 \%$ of the world fleet of fully container vessels and controlling around $77 \%$ of the container business. Moreover, $2 \mathrm{M}$ alliance and Ocean Alliance are controlling nearly $1 / 3$ of the market share each, while the Alliance is operating the largest vessels with an average of 6,346 TEUs/ ship, and controlling $17 \%$ of the world market share.

\subsection{Strength of shipping alliances in port operations}

Since the 90s, shipping lines have been involved in container terminal operations for the sack of controlling their business and squeezing cost, but, with the previously stated carrier's market concentration, port competition will strongly be affected. Table 1 shows the alliances members' involvement in port operation business in which nearly all carriers own and operate container terminals or berths, except Hapag-LIoyd and UASC. Moreover, Drewry predicts

Table 1 Alliances shipping companies activities in terminal operation business in 2017

\begin{tabular}{|c|c|l|}
\hline Alliance & Carrier & \multicolumn{1}{|c|}{ Terminal operation business } \\
\hline \multirow{3}{*}{$2 \mathbf{M}$} & Maersk Line & Owns "APM Terminals" which operates 76 port and terminal facilities in 95 countries \\
\cline { 2 - 3 } Ocean Alliance & MSC & Owns "Terminal investment limited" which is operates 35 terminals in 22 countries \\
\cline { 2 - 3 } & CMA-CGM & Owns “CMA Terminals" which operates 13 terminals worldwide \\
\cline { 2 - 3 } & COSCO & Operates 158 container berths in 30 ports worldwide \\
\cline { 2 - 3 } & OOCL & Operates 6 berths in USA and one in Taiwan \\
\hline \multirow{3}{*}{ The Alliance } & Evergreen & Operates 2 terminals in Taiwan and one in Panama \\
\cline { 2 - 3 } & K-Line & Operates 10 container terminals in 5 countries \\
\cline { 2 - 3 } & NYK-Line & Operates Container Terminals in 23 ports \\
\cline { 2 - 3 } & Yang Ming & Operates one terminal with 4 berths in Taiwan \\
\cline { 2 - 3 } & Hapag-Lloyd & \\
\cline { 2 - 3 } & UASC & \\
\hline
\end{tabular}

Source: Author

Table 2 Ranking of Terminal Operators from 2010 to 2020 (Forecast)

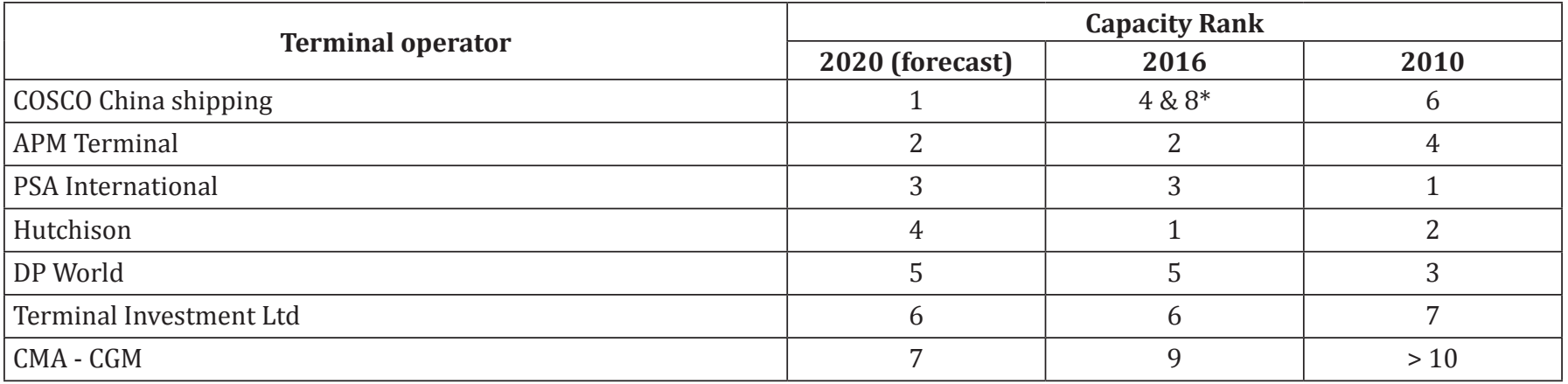

Source: Author, data taken from [7] 
that, by 2020, port operations will be leaded and dominated by carrier's companies. In the same concept, Table 2 presents the development of terminal operators ranking in which it is clear that COSCO will lead the industry by 2020 , followed by APM Terminals. In addition, the industry will witness 2 more shipping lines sister companies on top of seven operators. In addition, carriers are also involved in joint projects and own shares in some terminals managed by "terminal-only" operators [7].

\section{Impact of shipping dynamics on port competition}

These changes, taking place in the shipping industry, could strongly affect port competition as ports are a crucial part of this game. The carriers' policy to survive by cooling down the competition among them will exert pressure on many ports struggling to achieve their throughput targets. For example, the Malaysian Port Klang is expected to lose $10 \%$ of its annual throughput due to the new alliance formation (CMA-CGM and PSA International) as CMA CGM will shift destinations to Singapore [19], [1]. On the other hand, cooperation between container terminals and shipping alliances could increase the efficiency of terminal operations. Experts say "there is a need for more operational collaboration between terminals and shipping lines to help deal with issues such as peaking and productivity" [6]. Moreover, some ports worldwide have started some sort of cooperation to face these market conditions, by combining certain resources and utilize them jointly in an effort to maintain a competitive edge. This was firstly applied in 2001 between ports of Copenhagen and Malmo and was the first of a kind to have a cross-border alliance between ports. In 2015, another example of a similar cooperation took place between ports of Seattle and Tacoma in USA, with the focus on upgrading its terminal facilities and rail connections to further promote its competitive position [18].

\section{Conclusion}

Carriers competition in the last decade brought out the surplus in market carrying capacities with gigantic new vessels, coupled with weak market condition and poor recovering signs. This increases the desire for mergers and acquisitions, and further promotes formation of alliances to cool down the competition and to back up each other. This change in market dynamics increases the market concentration and the shipping lines bargaining power, and will defiantly affect competition among ports. Accordingly, one must ask for how long terminal operators, who are not a part of or operated by shipping liners, will survive with positive balance sheet, as the impact of shipping concentration will affect them sooner or later?

Consequently, ports should take a proactive standpoint and consider forming port alliances or clusters that would be the way to survive and increase their bargaining power in this dynamic market. In other words, it is justified to reconsider the co-petition concept or "cooperative competition" and imitate the carriers' policies, in particular because ports are not flexible and mobile as shipping lines are.

Ports are very essential for the supply chain of each country. Therefore, it is reasonable to expect from policy makers and governments to go hand in hand with ports to overcome the domination of shipping lines. In addition, taking into account geopolitics objectives too, regional agreements may also help and facilitate ports alliances, not only to support ports' survivability but also to secure the national objectives. The co-petition concept must be reasonable and have a footprint on the ground as an easy and effective solution that will warrant a win-win situation among all parties. Finally, further researches and studying could be addressed to evaluate the methodology of co-petition between ports as well as to establish how this concept will affect ports efficiency.

\section{References}

[1] Barnard B. (2017) CMA CGM, PSA double capacity at Singapore terminal. JOC.com Retrieved from the world wide web on 13 November 2017 from: https://www.joc.com/portnews/asian-ports/port-singapore/cma-cgm-psa-doublecapacity-singapore-terminal_20170328.html.

[2] Blaeser J., Jeff Drake J., Brian Nemeth B., and Pringle H. (2017) Global container shipping outlook for 2017: rearranging the deck chairs - with only a few seats in the sun. alixpartners . Retrieved from the world wide web on 12 November 2017 from: https://www.alixpartners.com/ insights-impact/global-container-shipping-outlook-for2017/\#sm.0000if5hofox0f4ht3g2noxahdbi2.

[3] Buxbaum P. (2017) Cosco Shipping to Acquire Orient Overseas International. Ocean Trade. Retreved from the world wide web on 19 November 2017 from: http://www.globaltrademag.com/global-logistics/cosco-shipping-acquireorient-overseas-international.

[4] Castillo-Manzano, J.I., Mercedes, C.N., Gonzalez Laxe, F., Lopez-Valpuesta, L. and Arevalo-Quijada, M.T. (2009) "Lowcost port competitiveness index: Implementation in the Spanish port system", Marine Policy, 33, pp. 591-598.

[5] Cullinane, K.P.B., Ji, P., and Wang, T-F. (2005) "The relationship between privatisation and DEA estimates of efficiency in the container port industry". Journal of Economics and Business, 57, pp. 433-462.

[6] Davidson, N. (2015, November). Unprecedented challenges: tackling the biggest ships and alliances. Port Technology International, (68), pp. 64-66.

[7] Drewry (2017) Global Container Terminal Operators Annual Review and Forecast 2017.

[8] Drewry Maritime Research (2017) Ports and terminal insights quarterly. Second quarter.

[9] Enna Hirata (2017) Contestability of Container Liner Shipping Market in Alliance Era. The Asian Journal of Shipping and Logistics, Vol 33. Issue 1, March 2017, pp. 27-32.

[10] Gavin M.,(2016) Bad news for Port Klang as CMA CGM signs up for container terminal JVwith PSA at Singapore. The loadstar. Retrieved from the world wid web on 7th of November from: https://theloadstar.co.uk/bad-news-for- 
port-klang-as-cma-cgm-signs-up-for-container-terminal-jvwith-psa-at-singapore/.

[11] H., Van de Voorde, E. \& Vanelslander, T. (2010) “It's all about economics! Port competition revisited" in Review of business and economics, 55(2), pp. 210-232.

[12] Haezendonck, E., and Notteboom, T. (2002) "The competitive advantage of seaports". In Huybrechts, M., Meersman, H., Van de Voorde, A., Van Hooydonk, E., Verbeke, A., Winkelmans, W., (eds), Port competitiveness: An economic and legal analysis of the factors determining the competitiveness of seaports. De Boeck Ltd, Antwerp, pp. 67-87.

[13] Hu, Y. , Zhu, D. (2009) "Empirical analysis of the worldwide maritime transportation network", Physica A, Vol. 388 No. 10, pp. 2061- 2071.

[14] ISL (2017) "Shipping statistics and market review 2017", Institute of shipping economics and logistics, Vo. 61, No. 7.

[15] Knight, F.H. (1921) "Risk, uncertainty and profit". Boston: Houghton Mifflin.

[16] Lopez E. ( 2017) COSCO buys O0CL for \$6.3B, Supply Chain Drive, Retrieved from the world wide web on 12 November 2017 from: https://www.supplychaindive.com/news/COSCO-buy-00CL-shipping-consolidation/446643/.

[17] Meersman, H., Van de Voorde, E. \& Vanelslander, T. (2010) "It's all about economics! Port competition revisited" in Review of business and economics, 55(2), pp. 210-232.

[18] Mongelluzzo, B. (2015). FMC gives green light to SeattleTacoma port alliance.Retrieved from the world wide web on 14 November 2017 from: http://worldmaritimenews.com/ archives/167313/fmc-gives-green-light-to-northwest-seaport-alliance/.

[19] Mooney T. (2017) New alliance impacts on Southeast Asia ports emerge. JOC.com Retrieved from the world wide web on 13 November 2017 from : https://www.joc.com/portnews/asian-ports/new-alliance-impacts-southeast-asiaports-emerge_20170428.html.

[20] Ng, K.Y. (2006) "Assessing the Attractiveness of ports in the North European Container Transhipment Market: An Agenda for Future Research in port competition". Maritime Economics \& Logistics, 8 (3), pp. 234-250.
[21] Notteboom T., de Langen P. (2015) Container Port Competition in Europe. In: Lee CY., Meng Q. (eds) Handbook of Ocean Container Transport Logistics. International Series in Operations Research \& Management Science, Vol. 220. Springer, Cham.

[22] Notteboom T.E., Parola, F., Satta, G. and Pallis A.A. (2017) The relationship between port choice and terminal involvement of alliance members in container shipping. Journal of Transport Geography, 64, pp. 158-173.

[23] Notteboom, T.E. (2004) 'Container shipping and ports: An overview', Review of Network Economics 3(2), pp. 86-106.

[24] Parola, F., Satta, G., Panayides, P.M. (2015) Corporate strategies and profitability of maritime logistics firms. Maritime Economics and logistics 17 (1), pp. 52-78.

[25] Power T., Mason T., Kapoor P. (2016) Consolidation in the liner industry, Drewry. Retrieved from the world wide web on 12 November 2017 from: http://www.porteconomics. eu/2017/04/20/the-puzzle-of-shipping-alliances-in-july-2016/.

[26] Rodrigue, J.P., Notteboom, T., 2010. Comparative north American and European gateway logistics: the regionalism of freight distribution. J. Transp. Geogr. 18 (4), pp. 497507.

[27] Sanchez J. and Mouftier L. (2017) The puzzle of shipping alliances in April 2017, Port Economics.

[28] Slack, B. (2007) "The terminalisation of supply chains". In: Wang, J., Notteboom, T., Olivier, D., Slack, B. (Eds.), Ports, Cities, and Global Supply Chains. Ashgate, Alderschot, pp. $1-50$.

[29] UNCTAD (2017), Review of maritime economy, p. 74.

[30] Wang, T-F., Cullinane, K., and Song, D-W. (2005) "Container port production and economic efficiency", Palgrave Macmillan, New York, USA.

[31] World Bank (2007) Port reform toolkit, Module2, The Evolution of ports in a competitive world. Washington DC: World Bank.

[32] World Bank (2001) "Port reform tool kit. Module 3, Alternative port management structure and owner ship models". Washington DC: World Bank. 